Adverse reactions develop in roughly one third of patients treated with gold, the proportion varying from $5 \%$, to $80^{\circ}{ }_{0}$ in several reported series. ${ }^{1}$ Eosinophilia occurs in roughly $5^{\circ}$ of patients and has been directly correlated with the development of gold toxicity. ${ }^{2}$ Vasomotor reactions to gold are not uncommon, but whether they indicate the development of more serious gold toxicity is unknown. Neurological complications, including peripheral neuropathy, myokymia, and a syndrome like the Guillain-Barré syndrome, ${ }^{3}$ have received little attention even in major textbooks of rheumatology. ${ }^{4}$ Encephalopathy has been reported: McAuley et al described a patient who recovered fully one month after treatment with gold was stopped. ${ }^{5}$

The severity of the illness in our patient, with residual neurological deficit nearly five months afterwards, shows the serious side effects that may occur during chrysotherapy.

1 Freyburg RH, Ziff M, Baum J. Gold therapy for rheumatoid arthritis. In: Hollander JL, McCarty DJ, eds. Arthritis and allied conditions. 8th ed. Philadelphia: Lea and Febiger, 1972:455-82.

Davis P, Hughes GRV. The significance of eosinophilia during gold treatment. Arthritis Rheum 1974;17:964-8.

Schlumpf U, Meyer M, Ulrich J, Friede RL. Neurological complications induced by gold treatment. Arthritis Rheum 1983;26:825-31.

Copeman W SC. In: Scott JT, ed. Copeman's textbook of the rheumatic diseases. McAinburgh: Churchill Livingstone, 1978

Psych DLF, Lecky BRF, Earl CJ. Gold encephalopathy. I Neurol Neurosurg

(Accepted 10 fanuary 1985)

Heath Road Wing, Ipswich Hospital, Ipswich, Suffolk IP4 5PD

M COHEN, BSC, MRCP, medical registrar

C P DAY, $M A, M B$, house physician

J L DAY, MD, FRCP, consultant physician

Correspondence to: Dr $M$ Cohen, Royal Alexandra Hospital for Sick Children, Brighton BN1 3JN.

\section{Nephrotic syndrome during treatment with interferon}

Interferon has activity against multiple myeloma.' In a trial of lymphoblastoid interferon A (Wellferon) given by ambulatory intravenous infusion for myeloma a patient with renal damage developed a nephrotic syndrome.

\section{Case report}

A 42 year old white woman presented with an IgGL myeloma in February 1980. Serum urea and creatinine concentrations were normal, hut her urine contained Bence Jones protein. She received oral melphalan, but the condition did not improve.

She was referred to us in June 1983 suffering from back pain. She was kyphotic. Investigations showed extensive lytic bone disease and heavy infiltration of bone marrow with myeloma cells. Serum urea and creatinine concentrations were normal, and her creatinine clearance was $82 \mathrm{ml} / \mathrm{min}$. The serum contained $45 \mathrm{~g} \mathrm{IgGI}$, paraprotein 1 . Urine contained $6 \mathrm{~g}$ protein with a trace of Bence Jones protein and a prominent leak of paraprotein. There was severe immune suppression, with a serum $\operatorname{IgA}$ concentration of $<0 \cdot 1 \mathrm{~g} / \mathrm{l}$. Intravenous cyclophosphamide produced transient benefit, but the disease progressed and in November she was admitted for a trial of interferon given by continuous intravenous infusion.

The figure shows the interferon dosage and urinary protein excretion. The urine volume was consistently about two litres daily. The maximum urinary protein concentration, 34 days after the start of interferon, was $37 \mathrm{~g} / \mathrm{l}$, with non-selective proteinuria including $14 \mathrm{~g}$ albumin $/ 1,11 \mathrm{~g}$ paraprotein $/ 1$, and $2 \mathrm{~g}$ lambda light chain/l. The electrophoretic patterns of serum and urinary protein were almost identical, indicating an almost complete leak. Her glomerular filtration rate was $44 \mathrm{ml} / \mathrm{min}$. Her serum albumin concentration fel to $17 \mathrm{~g} / \mathrm{l}$ and she developed bilateral ankle oedema. The serum creatinine concentration remained unchanged. Ultrasonography of the kidneys yielded normal results. There were no autoantibodies. Concentrations of $\mathrm{C}, 3$ and $\mathrm{C}, 4$ were slightly reduced, possibly owing to loss of protein in the urine. Tests for immune complexes ( $\mathrm{Clq}$ binding and the platelet aggregation test yielded negative results.
Interferon was stopped and the urinary protein concentration fell rapidly. Serum myeloma protein concentration had fallen during treatment, and this led us to try a further course of interferon three months later (figure). Her proteinuria immediately deteriorated but again fell rapidly when interferon was withdrawn. On this occasion the serum creatinine concentration rose from $138 \mu \mathrm{mol} / 1(1.6 \mathrm{mg} / 100 \mathrm{ml})$ before treatment to $181 \mu \mathrm{mol} / 1(2.0 \mathrm{mg} / 100 \mathrm{ml})$ during treatment and returned to $140 \mu \mathrm{mol} 1(1.6 \mathrm{mg} 100 \mathrm{ml})$ after interferon had been withdrawn.

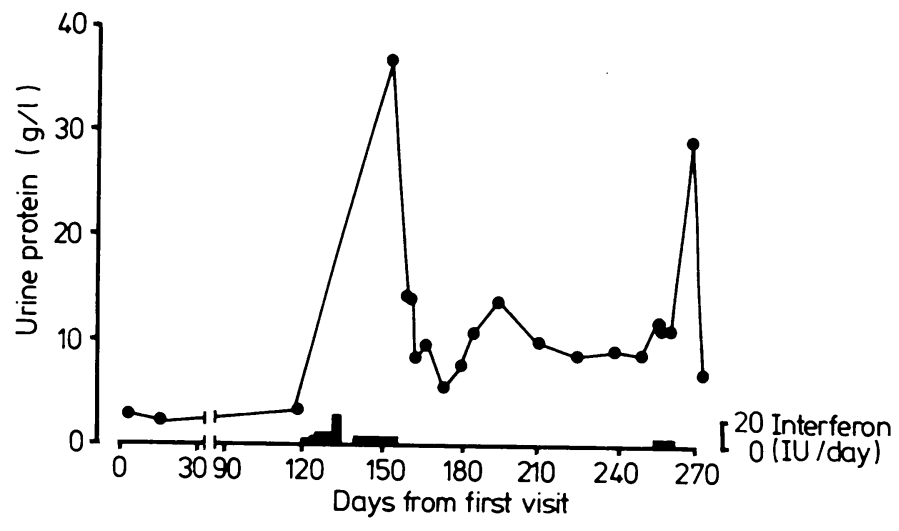

Dosage of interferon given and urinary protein excretion

\section{Comment}

In this case a nephrotic syndrome developed during treatment with interferon in a patient whose kidneys had been damaged by myeloma. The abnormality decreased when interferon was withdrawn but recurred when interferon was reintroduced. Although the nephrosis was rapidly reversed once interferon was stopped, evidence of renal damage remained.

Averbuch et al described a case in which intermittent intramuscular recombinant leucocyte interferon $A$ produced both a nephrotic syndrome and renal failure in a patient with mycosis fungoides." A renal biopsy specimen showed acute interstitial nephritis. Sherwin et al did not detect any evidence of a nephrotic syndrome in patients treated with leucocyte interferon A. ${ }^{3}$ Kra.ner et al described three cases in which interferon was given as an antiviral agent after renal transplantation."

We suggest that careful observation of all patients who are treated with interferon is necessary to avoid renal failure. Our observations suggest that the development of proteinuria, or an increase in its severity, may be the first indication of this complication and that

regular testing for urinary protein is essential during treatment with interferon.

1 Mellstedt $\mathrm{H}$, Ahre A, Bjorkholm M, et al. Human leucocyte interferon in the treatment of multiple myeloma. In: Matyer E, Schellekens F, eds. Biology of the ment of multiple myeloma. In: Matyer $\mathrm{E}$, Schelleke

2 Averbuch SI), Austin HA, Sherwin SA, Antonowynch T, Bunn PA, Longo DI Acute interstitial nephritis with the nephrotic synd $T$, Bunn PA, leukocyte interferon therany for mycosis fungoides. N Engl F Med 1984;310:32-5. 3 Sherwin SA, Knost JA, Fein S, et al. A multiple-dose phase I trial of recombinant leukocyte $\mathrm{A}$ interferon in cancer patients. $\mathcal{F}_{A M A}$ 1982;248:2461-6.

4 Kramer P, Ten Kate FWJ, Bijnen AB, Jeekel J, Weimar W. Recombinant leucocyte interferon $A$ induces steroid-resistant acute vascular rejection episodes in

(Accepted 28 fanuary 1985)

Royal Marsden Hospital, Sutton, Surrey SM2 5PT

P SEI.BY, MD, MRCP, lecturer in medicine

I KOHN, FRCPATH, professor of clinical pathology

J RAYMONI, BSC, scientific officer, department of clinical pathologv

I JUISON, MRCP, clinical fellow, department of medicine

T MCEI.WAIN, FRCP, professor of medicine

Correspondence to: Dr P Sclhy. 